\title{
Legal Protection For Foreign Investors In Tourism Sector Of Karangasem Regency
}

\author{
I Made Arjaya and Ida Bagus Anggapurana Pidada \\ \{info@warmadewa.ac.id\} \\ Universitas Warmadewa, Denpasar
}

\begin{abstract}
A tourism sector is a leading sector that provides many benefits for the community, especially to the Balinese. The Tourism Sector which is supported by cultural elements of the Balinese is a strong attraction for tourists to visit Bali. The high number of tourists has caused the tourism sector to have a strong attraction for investors to invest in Bali, including in Karangasem Regency. Thus, the aim of this study was to describe the effectiveness of the implementation of foreign capital protection in Karangasem Regency. The type of this study is juridical-empirical legal study. The approaches used in this study are the case approach, the statute approach, and the fact approach. The data sources used are primary data and secondary data. Data collection techniques are done by using interview technique and literature study technique. The high tourist attraction causes investment protection to be a very important thing to do. In increasing protection for investment in Karangasem Regency, local governments have implemented regulation that are in accordance with international and national legal frameworks. As for its implementation in Karangasem Regency, it still has various obstacles, but the Karangasem Regency government has carried out various strategies in overcoming these obstacles. In addition, the role of local communities is also very influential in encouraging the increased of foreign investment and providing protection for businesses development carried out by foreign investors.
\end{abstract}

Keywords: Legal Protection, Foreign Investors, Investment, Tourism Sector

\section{Introduction}

Tourism as a generator of the economy of the global community is a paradox, on the one hand tourism is in touch with the welfare of society, on the other hand tourism requires land (land) for activities both as hotels, restaurants and other facilities in contact with tourism [1]. Tourism sector is indeed a leading sector that provides many benefits for the welfare of community, especially for the Balinese. The Tourism Sector, supported by elements of Balinese culture, is a strong attraction for tourists to visit Bali. The high number of tourists has caused the tourism sector to have a strong attraction for investors to invest in Bali. The great benefits of the tourism sector also have a negative impact that can be a threat if it is not regulated and implemented properly. Investment in the tourism sector, especially in hospitality field, is open to foreign investors both full and joint ventures. The presence of foreign 
investment is not only expected to advance the industry towards modernization but also can increase foreign exchange, regional government revenues, economic growth, improvements in employment fields, knowledge and technology [2].

In carrying out foreign investment in the tourism sector is regulated in the laws and regulations of the Republic of Indonesia. Regulating the activities of foreign investors in their investment activities in Indonesia in the field of hospitality is regulated in laws number 25 of 2007 concerning Investment and Regulation of the Head of the Investment Coordinating Board Number 5 of 2013 concerning Guidelines and Procedures for Licensing and NonInvestment Licensing. Besides that, Bali Province Regulation Number 16 of 2009 concerning the Bali Province Spatial Plan 2009-2029 which regulates more detailed provisions regarding investment in the tourism sector, especially in the hospitality sector in Bali, has also been regulated. Although it has been clearly regulated regarding the provisions in investing in the hotel sector in Bali, there are still many violations in the sector. These violations are certainly very detrimental the government, the community and also the investors. One of them is in Karangasem Regency which is one of tourism destinations that still has great potential to be developed. Karangasem Regency is one of 9 Regencies/Cities in the province of Bali that is developing into a destination for spiritual tourism on the island of Bali, with the existence of the Great Besakih Temple, Lempuyang temple and tourist destinations that are no less beautiful than other tourist areas in Bali. In addition to spiritual tourism, Karangasem also has a potential of natural tourism that has a great potential to be developed, besides that there are also many historical buildings inherited from the Dutch colonial era such as Taman Ujung and Tirta Gangga. Seeing this potential is certainly a big attraction for foreign investors if it is managed properly so as to prevent violations and fraud in the tourism industry sector.

The violations and fraud on investments related to tourism are very worrying for economic development in the Karangasem area. This is because fraud in the tourism investment sector in addition to harming the government can also cause concern to investors who want to invest in the vital sector in Bali. Investor protection is a very important thing that must be upheld by the government of Indonesia Republic, including the diversion of the Karangasem region.

Foreign investors need protection to do business in Indonesia. Government policies that support investors for investment security will be a big interest to invest in Indonesia. In order to bring in investors who want to invest, it is necessary to build a conducive environment, employment and licensing that can benefit each other. In protecting foreign capital, the government of the Republic of Indonesia has stipulated Article 5 paragraph (2) of Laws number 25 of 2007 concerning Investment which has been clearly stipulated regarding the legal form of foreign investment companies. Foreign investment must be in the form of a limited liability company. Foreign investment in Indonesia can be done by foreign parties / individuals or legal entities into a company that is one hundred percent cultivated by foreign parties or by combining foreign capital with national capital. In addition, the government of the Republic of Indonesia has also regulated closed and open business entities in an investment as stipulated in Presidential Regulation Number 44 of 2016. Based on a set of rules that has been established, it has shown the high attention of the government of the Republic of Indonesia in protecting foreign investment.

A number of latest related study about legal protection has been done. Pasaribu \& Sulistiowati (2014) conducted a research about legal protection for foreign investor in Mining sector. In that research result showed that Basic Regulation to make policy in Investment of Mining still use and managed in Number Law 25 of 2007 about Investment and Number Law 4 of 2009 about Mineral and Coal Mining. This Law was regarded by the government as the basic rules and still valid with Indonesia's current situation. The second latest related study 
was about legal protection for foreign investment in facing the ASEAN economic community of 2015. The study is conducted to see the legal protection for foreign investment in facing the ASEAN economic community of 2015. The research found that the government must be able to attract investors to invest in Indonesia with a number of legal protections needed in various fields that can attract investors, namely political factors, economic factors, and legal factors (Dewi, 2014). Based on the problem discussing on the latest related above, therefore, further research is needed to be carried which has aim to describe the effectiveness of the implementation of foreign capital protection in Karangasem Regency.

\section{Method}

This type of study is juridical-empirical legal study. The empirical juridical method is carried out by conducting direct observations in the field. Thus, this type of research is the appropriate type of research in measuring an effectiveness of legal protection for investment in the tourism sector of Karangasem Regency in terms of its implementation in the community. The approaches used in this study are the case approach, the statute approach, and the fact approach. The data sources used are primary data and secondary data. Data collection techniques are done by using interview technique and literature study technique. The research location is in the Karangasem Regency.

\section{Discussion}

\subsection{Regulatory of Foreign Investment in International Law and National Law Framework}

Karangasem Regency Government in regulating the implementation of protection of foreign investment in Karangasem Regency is inseparable from the framework of international law and national law which are used as guidelines in encouraging increased investment which is expected to be able to provide welfare benefits for the people of Karangasem.

In order for national law to always be able to adjust the development of the situation, then the law must be ready to open up, accept external elements that can facilitate national development that is being carried out by the Indonesian Nation [3]. As stated by the research team from the National Legal Development Agency from the point of national interest, the presence of Law Number 1 of 1967 can fulfill the mandate outlined by the 1945 Constitution and MPRS Decree Number XXIII / MPRS / 1966 [4]. The issuance of Law Number 1 of 1967 regarding Foreign Investment while regulating the rights and obligations of foreign investors, providing guarantee of legal certainty and guarantee of business certainty, thus this regulation can clearly improve legal protection of foreign investors about how the capital will be invested in Indonesian territory. In its development to date, the investment law has undergone amendment especially related to its governance in the field of government and the acceleration of development in Indonesia, particularly after being issued the Laws number 25 of 2007 concerning Investment which regulates Foreign and Domestic Investment. This condition shows that the protection of the law against foreign investment in Indonesia is increasingly being considered by the government. This is because the legal protection has a major influence on the development of national development. 
In order to realize a rapidly developing of national development in addition to manage domestic capital, there is also a need for foreign capital brought by foreign investors. Foreign investors also need legal certainty and consistency of central government policies. The fear of foreign investors is a drastic change in the economic and political fields that can cause a crisis. The condition of the economic crisis is very detrimental the investment, especially investment in the tourism sector. The development of the Investment agreement at the end of 1990 showed that the principles of developmental protection were increasingly formed as a standard of protection. This development built up two standards of protection, they are Absolute and Relative Standards [5]. Absolute standards are standards of treatment given to investments in a country without pay attention to the treatment of investments in other countries. This standard provides justice for both domestic and foreign investors in order to be able to compete fairly without discrimination by local governments of Karangasem Regency and the communities around them. While the relative standard is a treatment taking into account the treatment received by investments from other countries. By applying this standard, investors who invest in a number of countries do not feel burdened with a regulation because it is also applied in other countries. This absolute standard and relative standard are also applied as a regulatory framework in protecting foreign investors who want to invest their capital in Karangasem Regency.

\subsection{Regulations of Foreign Investment Protection in Karangasem Regency}

Laws number 25 of 2007 concerning Investment in Article 30 is mandated in order the Regional Government is more empowered both in developing potential in each region and in coordinating of promotions regarding tourism and investment services.

The regulation of foreign investment protection has been clearly regulated in national regulations while in regional such as Karangasem is more concerned with how these rules can be applied in its implementation in the regions. This was stated by I Wayan Laba Erawan as a Head of the One Stop Integrated Services and Investment Service of Karangasem Regency.

Karangasem Regency Government guarantees the protection of foreign investment in Karangasem Regency as long as the investors have met requirement stipulated such as space utilization permits, environmental permits, building permits, business permits and have obtained principle approval from the Regent. In addition, the government also conducts socialization before the permit was issued to the surrounding community so that the interests of the surrounding community were not neglected, especially those who were potentially disadvantaged. To help investors in carrying out their business activities so as not to experience setbacks or bankrupt, periodically the One Stop Investment Service and Integrated Service conducts activities through monitoring and evaluating the realization of investments in Karangasem Regency. At the time of coaching, a team which was formed through a Regent Decree consisting of cross agencies (regional apparatus) enter directly the location of the business to ascertain what was the obstacle of the businessman in carrying out his business and how his business prospects going forward. The implementation of Investment Monitoring and Evaluation activities in Karangasem Regency is expected to provide a real situation of investment growth and development, investment problems and constraints faced by investors in carrying out their investments in Karangasem Regency.

In the implementation of monitoring and evaluation is focused on the Approval Letter issued by the government in this case the Investment Coordinating Board of the Republic of Indonesia for the Karangasem Regency region as well as the Licensing Documents which are recorded in the PMPTSP Office of Karangasem Regency. This was done by considering the lack of information on investment developments because most investors did not submit reports 
on investment activities that were sent / reported to the PMPTSP Office of Karangasem Regency, as mandated by the Head of Coordinating Board of the Republic of Indonesia Number 13 of 2009 which was amended with regulation of head of Indonesia Republic Coordinating Board Number 7 of 2010 concerning Guidelines and Procedures for Controlling Investment Implementation Article 11 paragraph (1).

\subsection{Problems of the Karangasem Regency Government in Providing Legal Protection to the Tourism Sector Investment.}

The interest of the international community to invest (foreign investors) in Karangasem Regency is not maximal, considering various things such as the availability of supporting factors in the tourism sector, transformation facilities and other infrastructure that support inadequate investment development and the unfavorable investment climate in Karangasem Regency- caused as follows:

1) The investment climate that has not been good with the situation of Mount Agung after the eruption in 2017 which until now (2019) is still in Alert III status. This caused fear from the capital owners to invest in Karangasem Regency. Some investors even closed their business activities after that eruption such as Emeral Hotels and Dream Resorts in Tulamben Village, Kubu District.

2) Regulations at the regional and central level have not been synchronized with the implementation of investment and licensing related to the location of Tourism Destination Objects which can be granted or not. Regulations that are urgently needed for legal certainty are the certainty of Protected Forest areas, Determination of Regional Spatial Planning and Spatial Detail Plans which enter the Green Zone, determination of industrial zones, residential zones and other zones.

3) Not maximum yet the carrying capacity and capacity of the investment potential of the region in Karangasem Regency which can increase the attractiveness of tourists thus foreign investors can get maximum profits.

In order to overcome these problems, the Karangasem Regency Government explores the region's superior potential in Karangasem Regency by carrying the tagline "Karangasem The Siprit of Bali" by the regent of Karangasem, I Gusti Ayu Mas Sumatri. The regional government has signed the Memorandum of Understanding with 189 traditional Villages throughout Karangasem Regency to develop all the potential in each of the traditional villages in accordance with the potential in their respective traditional villages, both the potential of Natural Resources, Human resources, creative industries, culinary, trade, tourism and culture as well as encouraging the realization of Tourism Villages in each customary village, $\overline{\bar{j}}_{\text {. }}$ this was introduced by the name of the program "Realizing a customary Village based tourism Villages". Each Tourism Village was formed a Tourism Awareness Group, which has task and function to develop the village into a tourism village, especially spiritual tourism.

In addition, the Karangasem Regency government is increasing infrastructure development and developing supporting facilities in tourism destinations in Karangasem. The matter is intended to increase the attractiveness of both foreign and domestic tourists thus it indirectly benefits both foreign and domestic investors.

\subsection{Participation of Karangasem Local Communities in Foreign Investment protection in Karangasem Regency}

Communities that living in investment areas have many roles in supporting existing investments. The development of a region with the presence of investors is also inseparable from the support of the local community who contributes to the progress and improvement of 
local community welfare. The Karangasem Regency Government forms a tourism conscious community in each village which has aim to increase the active role of the community to be directly involved in advancing tourism potential in its area. This tourism conscious group has various forms of activities such as from building road access to the simplest, mutual cooperation activities to clean the environment. This tourism conscious group not only receives assistance from the district government, but can also submit funds to the center through village fund allocation.

The participation of other local communities can be seen clearly along the Jasri beach, Subagan Village, Karangasem. Many locations are built by foreigners as villas owned who work with local residents, especially on the Jasri beach. Foreign investors are considered not to interfere the activities in the village. In addition, the presence of villas along the beach of Jasri has an impact on improving the welfare of community in their environment.

Meanwhile, according to Nengah Sukiyani, a trader who sells daily on the edge of Jasri Beach claims to support the presence of foreign investors in his area. The reason is because foreign investors are considered not to disturb and have never made a problem with local residents. However, these investors rarely communicate with local residents because of the limited knowledge of local residents to communicate using foreign languages. Nonetheless, local residents always greet every passing foreigner either by saying hello or by smiling and other body language. One of the Investors at Jasri, who is usually called Mr. Art, helps children of local residents to be able to go to school for free.

Meanwhile, based on an interview with Komang Juwantara, the manager of the villa in Jasri also gave a statement that his party supported the presence of foreign investors in his village. All The villa are still in the ownership name of a local resident named Mr. Tarsa but has been bound by an agreement in a Notary to foreigners. Even so, the investors contribute by giving 1.000 .000 rupiah annually to the traditional Village. The amount is considered not burdensome investors as assistance social.

Investors besides obtaining profits with their business activities, every investor must provide Corporate Responsibility or Corporate Social Responsibility (CSR) to improve welfare and help deal the social problems that exist in their environment. Thus, there will be a reciprocal relationship between investors and local communities.

\section{Conclusion}

Based on the results of this study, it can be concluded that legal protection in the tourism sector in Karangasem Regency has been well implemented. The indicators are as follows:

1) The principles of international and national law have been applied as a framework in regulating the implementation of protection against foreign investment.

2) There are efforts to improve the quality and grow new tourism destinations based on traditional villages.

3) Periodically conducting coaching activities in conducting investor monitoring.

4) There have been promotions to increase foreign and domestic tourist visits to increase the competitiveness of investors.

5) Implementation of One-Stop Integrated Services in investment field which is supported by an online license and information service system and the application of bureaucratic reform to facilitate investors in starting their business activities.

6) Infrastructure development that is intensively carried out. 
7) There is monitoring to prevent irresponsible investments.

8) Encourage community involvement through tourism conscious groups

Although there are still obstacles that cannot be avoided, the Karangasem Regency Government has implemented a strategy to reduce or resolve these problems.

\section{References}

[1] I. W. W. Astara, Korelasi Hukum, Budaya dan Pariwisata Bali Dalam Masyarakat yang Berubah: Membuka Jalan Keilmuan. Denpasar: Pustaka Larasan, 2015.

[2] R. Rakhmawati, Hukum Penanaman Modal di Indonesia. Malang: Banyumedia, 2005.

[3] B. Lopa, Etika Pembangunan Hukum Nasional dalam Artidjo Alkostar, Identitas Hukum Nasional. FH UII Jogjakarta, 1997.

[4] F. Rajagukguk, Bilateral Investation teaties 1995-2006 in the Mid 1990. New York: United Nation, 1985.

[5] UNCTAD, Bilateral Investation teaties 1995-2006 in the Mid 1990. New York: United Nation, 1998. 